\title{
炭素および AlN 上における 溶融マグネシウムの濡れ*1
}

\section{石雯*2 小橋 畺 長 隆郎}

名古屋大学工学部材料プロセス工学科

J. Japan Inst. Metals, Vol. 64, No. 5 (2000), pp. 335-338

Papers from JIM Fall Meeting (1999)

(C) 2000 The Japan Institute of Metals

\section{Wettability of Molten Magnesium on Carbon and AlN}

Wen Shi*2, Makoto Kobashi and Takao Choh

Department of Materials Processing Engineering, School of Engineering, Nagoya University, Nagoya 464-8603

Good wettability between molten metals and solid ceramics is important to fabricate metal matrix composites via a casting route. In this work, the wettability of molten magnesium on carbon and AlN substrate was evaluated. To stabilize the shape of the magnesium drop, the chamber was filled with magnesium vapor prior to the wettability measurement. A good wettability was observed from the magnesium-carbon system. Initial contact angles of molten magnesium on the vitreous carbon and the porous graphite at $973 \mathrm{~K}$ were $80^{\circ}$ and $74^{\circ}$, respectively. However, the molten magnesium did not show good wettability with AlN. The initial contact angle of molten magnesium on AlN was $119^{\circ}$. The effects of aluminum and zinc addition on the contact angle were also measured. The contact angle of molten $\mathrm{Mg}-\mathrm{Al}$ alloy on $\mathrm{AlN}$ substrate were almost constant $\left(119^{\circ}\right)$ for aluminum additions in the range of 0 to 3 mass $\%$, but mildly reduced to $115^{\circ}$ when 10 mass $\%$ of aluminum was added. The contact angle of $\mathrm{Mg}-10$ mass $\% \mathrm{Zn}$ alloy on AlN substrate was $107^{\circ}$, which again was slightly lower than that of pure magnesium.

(Received December 17, 1999; In Final Form February 28, 2000)

Keywords: wettability, sessile drop method, contact angle, magnesium, graphite, AlN

\section{1. 緒言}

マグネシウム基複合材料あるいはマグネシウム材料そのる のは軽量という観点に抮いて優れている。このなかでも，複 合材料については適切な製造プロセスの開発が急務とされ， 溶融マグネシウムと固相間に和ける濡れ性，反応あるいは諸 成分の挙動を十分把握することが欠かせない(-3)。また，、 グネシウム系材料を構造材料や電子材料とするためには，七 ラミックスとの良好な接合技術の確立が望まれ，したがっ て，接合の微視的メカニズムを解明するために，同様に濡れ 性の基礎データが必要になると思われる。しかしながら，溶 融マグネシゥムに関しては濡れ性測定が難しく，これまでマ グネシウムとセラミックス間の濡れ性に関する研究報告はほ とえど見られない。

そこで，本研究では，まず高弾性率の炭素紻維強化マグネ シウム複合材料の開発を想定して炭素質材料，さらには， $1713 \mathrm{~K}$ 以下の真空中では熱的に安定であり，他方，溶融マ グネシウムに対しては化学的に安定なことから鋳型材料とし

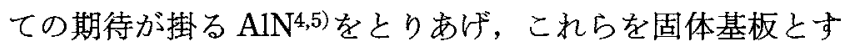
る溶融マグネシウムによる濡れ性を測定することにした.

*1 1999年11月22日日本金属学会秋期大会に批いて発表

*2 名古屋大学大学院生 (Graduate Student, Nagoya University)

\section{2. 実 験 方 法}

炭素質材料基板として使用するものは寸法が $20 \mathrm{~mm} \times 20$ $\mathrm{mm} \times 3 \mathrm{~mm}$ のガラス状炭素扣よび多孔質黒鉛であり，それ ぞれの組成をTable 1 に示す。また，AlN 基板は焼結助剂 として $\mathrm{Y}_{2} \mathrm{O}_{3}$ を\%含むものを用い，そのサイズは $25 \mathrm{~mm}$ $\times 25 \mathrm{~mm} \times 0.6 \mathrm{~mm}$ である。これら基板の表面はダイヤモン ド(粒径 $1 \mu \mathrm{m})$ にってバフ研磨を施した。だだし，濡れ性 に対する基板表面粗さの影響を調べるため，A1N 基板につ いては表面粗さ $1 \mu \mathrm{m}$ の基板(AlN-1) 以外に，\#120の SiC 研磨紙で研磨したますの表面状態が粗な基板 (AlN-2)を使用 した。一方，滴下材としては炭素質基板に打いては純マグネ シウム, $\mathrm{AlN}$ 基板では純マグネシウムのほか $\mathrm{Mg}-\mathrm{Al}, \mathrm{Mg}-$ $\mathrm{Zn}$ 合金を使用した。これらの基板とマグネシウム滴下材は 実験直前に超音波洗浄処理を行った。な执，溶融マグネシウ ムと固体基板間の需れ性測定を安定に行うため, 液滴の蒸発 抑制，気液括よび固気界面エネルギーの平衡值への接近，さ らには酸化防止を目的として，滴下材と同じ組成のマグネシ ウム蒸発源を別に設けて, そこから蒸気を発生させた後, 液 滴滴下を行ら方法をとっだ

本研究で用いた静滴法の実験装置図を Fig. 1 に示す. 加 熱には赤外線イメージ帄を用いた。まず透明石英管の中央部 
Table 1 The impurity level of porous graphite and vitreous carbon substrates.

(ppm)

\begin{tabular}{ccccccccccccccccccccccc}
\hline Element & $\mathrm{Li}$ & $\mathrm{Bi}$ & $\mathrm{Na}$ & $\mathrm{Mg}$ & $\mathrm{Al}$ & $\mathrm{Si}$ & $\mathrm{K}$ & $\mathrm{Ca}$ & $\mathrm{Ti}$ & $\mathrm{V}$ & $\mathrm{Cr}$ & $\mathrm{Mn}$ & $\mathrm{Fe}$ & $\mathrm{Co}$ & $\mathrm{Ni}$ & $\mathrm{Cu}$ & $\mathrm{Zn}$ & $\mathrm{Pb}$ \\
\hline Porous graphite & $<0.03$ & 3 & $<0.5$ & 0.2 & 14 & 2 & 2 & 6 & 33 & 40 & $<0.3$ & $<0.2$ & 26 & $<0.3$ & 4 & $<1$ & $<0.6$ & $<1$ \\
\hline Vitreous carbon & & & $<0.05$ & & $<0.08$ & & $<0.1$ & $<0.04$ & $<0.09$ & $<0.07$ & $<0.07$ & & $<0.04$ & $<0.1$ & $<0.008$ & & \\
\hline
\end{tabular}

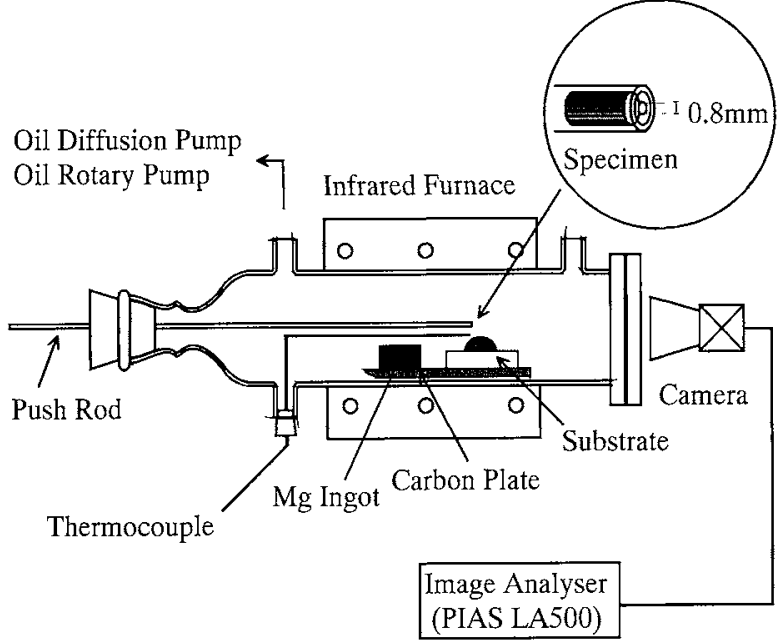

Fig. 1 Schematic illustration of the experimental apparatus for the measurement of the contact angle.

に基板を水平に設置し，次に先端に穴を有するアルミナ滴下 棒に滴下用マグネシウム円柱状試料を入れた後，これを基板 中央に液滴が落ちるよらに設定した。ささらに，蒸発源のマグ ネシウム塊をアルミナ製ボートに入れ，基板の横に設置し た、実験操作としては，まず，吸着不純ガスを除去するた め，装置内を $573 \mathrm{~K} に て ， 1.33 \times 10^{-3} \mathrm{~Pa}$ をで真空排気して $1200 \mathrm{~s}$ 間保持した。次に，排気を止めて，測定温度の 973 $\mathrm{K}$ をで昇温し，180 $\mathrm{s}$ 間保持してマグネシウム蒸気を反応管 内に満たした。矢の後直ちに試料液滴を基板上に静かに滴下 し，CCDカメラで側面から液滴を撮影した。液滴の対称性 が最もよい静止映像中の滴形状について画像解析装置(PIAS LA500)を用いて，接触角を直接測定した。ただし，液滴の 質量は約 $0.2 \mathrm{~g}$ とした。また，濡れ性の評価は，滴下による 液滴の振動が収まることが確認された時点(滴下 $3 \mathrm{~s}$ 後)の接 触角を初期接触角として用いて行い，接触角の経侍変化につ いてはこの值を需秒としてプロットした。

\section{3. 実験結果および考察}

\section{1 マグネシウム/炭素質基板系}

Fig. 2 は，973 Kに扣ける二種類の炭素質基板と溶融マグ ネシウム間の接触角，また，Fig. 3 は液滴直径の経時変化を 示す．初期接触角と乙ては，マグネシウム/ガラス状炭素系

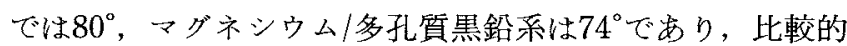
良い濡れ性が得られた。また，時間の経過ととるに接触角は 低下するが，液滴の直径は泀とんど一定值を示している。こ のような接触角の低下は液滴の蒸発によって生じる後退接触 角が時間とともに現われ始めることを示す。しだって，マ

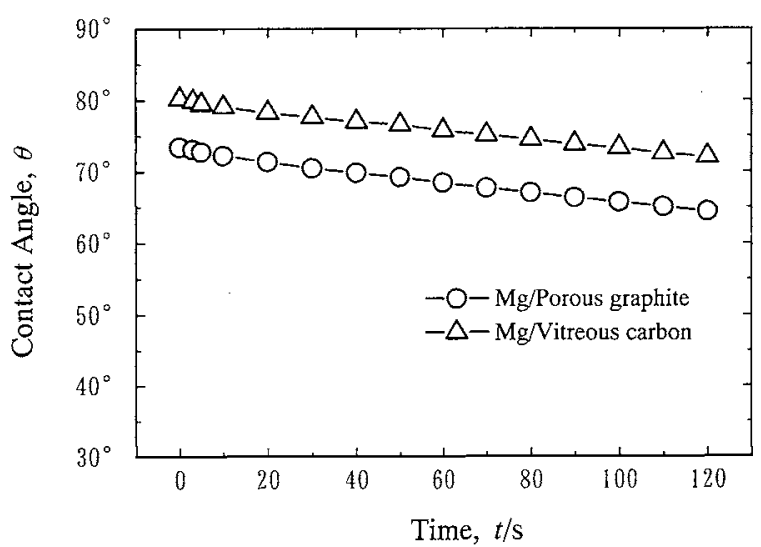

Fig. 2 Effect of the holding time on the contact angle of $\mathrm{Mg}$ /porous graphite and $\mathrm{Mg} /$ vitreous carbon systems at $973 \mathrm{~K}$.

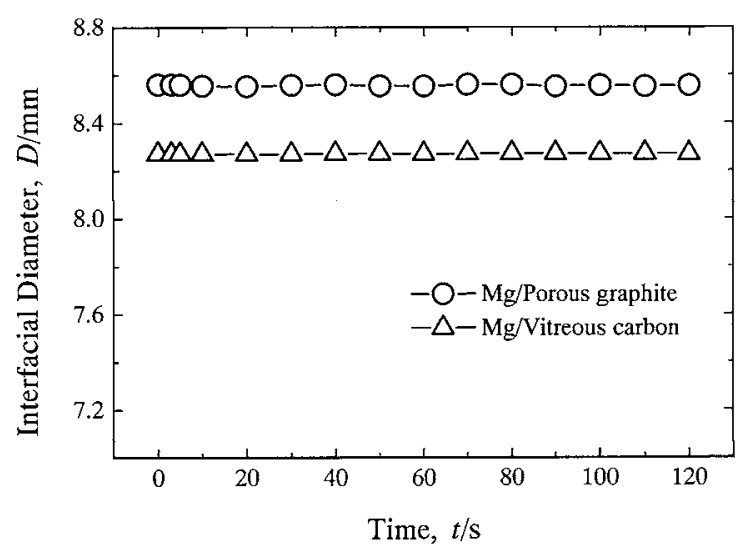

Fig. 3 Effect of the holding time on the interfacial diameter of $\mathrm{Mg} /$ porous graphite and $\mathrm{Mg}$ / vitreous carbon systems at 973 $\mathrm{K}$.

グネシウム蒸発源の使用によってマグネシウムの蒸気圧を平 衡に近づけるよ5にした沈るかからず，尧発速度は遅い が，液滴からのマグネシウム蒸発も同時に進行し，これを完 全に抑制できないことを意味する。

また，接触角測定終了後，常温に拈いて滴下試料/基板界 面について SEM 観察を行った結果，二つの系のいずれにも 明確な界面反応相住認められなかった。ただし，多孔質黒鉛 の場合には湘定後の泠却中に静滴と基板との熱膨張係数の差 により静滴が基板から離れ，腺間が見られた。一方，ガラス 状炭素基板上の静滴はこのよらな剥離はなかった。したがっ て，マグネシウムとガラス状炭素間の界面結合は良好である が，多孔質黑鉛の場合には界面に存在する気孔によって剥離 が促されたと思われる。

ここで，Fig. 2 の結果を考察する.本研究で用いた二種類 
の炭素質基板は純度あるいは表面性質において異なるので， それにより接触角が影響を受けることが予想される。このう ら純度による影響を検討することは難しいが，ガラス質炭素 の純度は多孔質黒鉛より高く，季た，表面も比較的平坦なの でこの系の測定結果はより高純度炭素質材料の値に近いと 考兄られる。一方，多孔質黒鉛の場合は空孔の存在による表 面の凹凸，つまり基板の表面粗さに伴ら影響を配慮すべさで あろら．表面粗さの影響を表わす関係式としては Wenzel の 式が知られている7). それによれば，表面が粗面になると， 表面積が平滑面の $m$ 倍になり，粗面に括ける見掛けの接触 角 $\theta_{m}$ と平滑面の接触角 $\theta$ とは

$$
\cos \theta_{m}=\mathrm{m} \cos \theta
$$

によって関係づけられる。ただし， $-1 \leqq \mathrm{~m} \cos \theta \leqq 1$ を満足 しなければならない。したがって，良好な濡れ性を表示する $\theta<90^{\circ}$ に打いては， $\theta_{m}<\theta$ となり，粗面は濡れ性をさらに改 善するが，一方， $\theta>90^{\circ}$ では $\theta_{m}>\theta$ となって，逆に需れ性を 一層悪くする．この関係をさきの結果代当て嵌めると，マグ ネシウム/炭素質基板系の接触角はいずれも $\theta<90^{\circ}$ 範用に あるので，多孔質黒鉛系では表面粗さが原因してより低い值 を示すはずである。

この汪か Fig. 2 の結果について，固気界面エネルギー $\gamma_{\mathrm{sv}}$ の立場から考考察を試みる. Young の式から導かれた

$$
\cos \theta=\left(\gamma_{\mathrm{sv}}-\gamma_{\mathrm{sl}}\right) / \gamma_{\mathrm{lv}}
$$

において, 気液界面エネルギー $\gamma_{\mathrm{lv}}$ の值は本研究の二つの系 については同じとみなすことができる。したがって，これら の系の接触角に対する影響因子は $\left(\gamma_{\mathrm{sv}}-\gamma_{\mathrm{sl}}\right)$ となる。ただし， $\gamma_{\mathrm{SI}}$ は固液界面エネルギ一とする。ところで，良好な濡れ性 を示寸 $\theta<90^{\circ}$ では $\gamma_{\mathrm{sV}}>\gamma_{\mathrm{s} 1}$ の関係が成立し，これはまた両界 面エネルギーの差 $\left(\gamma_{\mathrm{sv}}-\gamma_{\mathrm{sl}}\right)$ が増大すると， $\theta$ は低下し，濡れ 性はますます向上することを子意味する。专こで，基板の固 気界面に吸着されるマグネシウム蒸気原子量の基板表面状態 への依存関係に注目する.Fig. 4 は滴下実験終了後のガラス 状炭素と多孔質黒鉛基板の固気界面の SEM 写真とマグネシ ウムのイメージ分析結果を示す，定量的な結論は出せない が，全体的に多孔質黒鉛基板に吸着されたマグネシウム量は 多い上らに見受けられる。特に空孔とその周囲に存在するマ グネシウム量は相当に多い，それに対して，ガラス状炭素基 板に持けるマグネシウム量は均一で，多孔質黒鉛基板上り少 ない，したがって，表面にめるマグネシウム原子量が多くな るにつれて固気界面エネルギー $\left(\gamma_{\mathrm{Sv}}\right)$ の值が大きくなると考 光られるの゙，この奇与が $\gamma_{\mathrm{sl}}$ の変化比べて増大して $\left(\gamma_{\mathrm{sv}}\right.$ 一 $\left.\gamma_{\mathrm{S}}\right)$ の值が大きくなり，これに伴ってマグネシウム/多孔質 黒鉛系の接触角は低下したとも推定される。

\section{2 マグネシウム/AlN 基板系}

\subsection{1 純マグネシウムによる濡れ}

Fig. 5 表面粗さ $1 \mu \mathrm{m} の \operatorname{AlN}(\mathrm{AlN}-1)$ 抢よびエメリ一紙 （\#120）によって表面を粗くした $\mathrm{AlN}(\mathrm{AlN}-2)$ を用いたとさ の $973 \mathrm{~K}$ に和ける接触角の経時変化を示す。マグネシウム AlN-1系の初期接触角の值は119であり，マグネシウム/

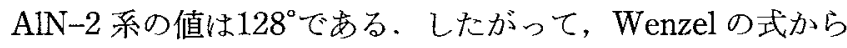
予想されたよらに，接触角が悪い濡れ性を表す $\theta>90^{\circ}$ の領
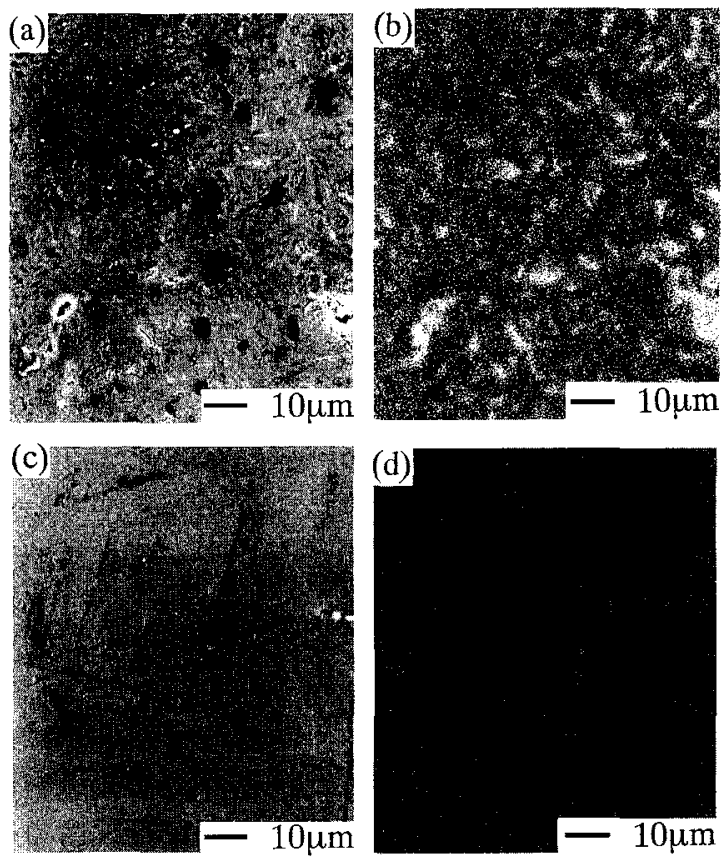

Fig. 4 Results of EPMA analyses for adsorption of magnesium on porous graphite and vitreous carbon substrates: (a) SEM of porous graphite, (b) Mg image of porous graphite, (c) SEM of vitreous carbon, (d) Mg image of vitreous carbon.

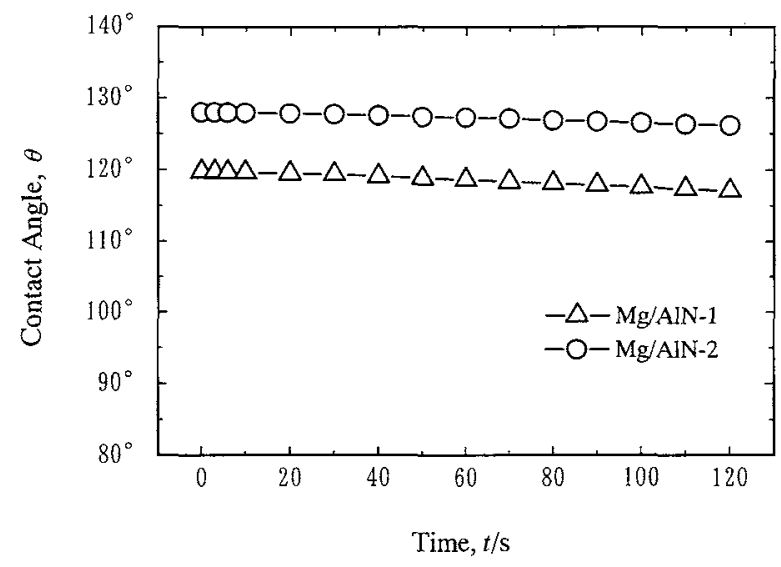

Fig. 5 Effect of the holding time on the contact angle of pure magnesium on AlN substrate at $973 \mathrm{~K}$.

域にあるので，基板表面が粗くなることによって，接触角が 大さくなることが証明され，また，この関係は前述のマグネ シウム/炭素質基板系とは逆の関係にある. 特に, マグネシ ウム/AIN-1 系に関しては，本研究に和いて取り扱った系の 中で最子悪い濡水性を示し，また，この表面を粗面にするこ とにより，さらに濡れ性を低下させることができたことは， この材料がるつ滦や鋳型材料として有望なことを示吉.

な拈，これらの系に扣いてもマグネシウム/炭素質基板系 と同じようK，接触角は時間経過とともに減少している。乙 かし，この系の接触角は大きく，液滴の比表面積が小さいの で, 全体の蒸発量は少なく, 接触角の低下する程度はより小 さくなる，さら飞液滴と基板との接触直径の経時変化も認め られていないので，接触角は時間とともに後退接触角へ移行 することが考兑られる。 


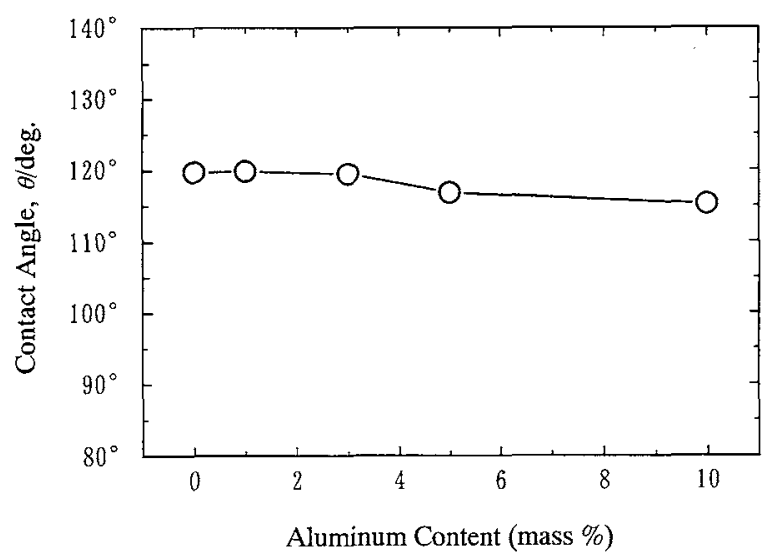

Fig. 6 Effect of aluminum content on the initial contact angle between $\mathrm{Mg}-\mathrm{Al}$ alloy drop and $\mathrm{AlN}-1$ substrate at $973 \mathrm{~K}$.

\subsection{2 $\mathrm{Mg}-\mathrm{Al}$ 合金による濡れ}

Fig. 6 は，973 K に拈けるマグネシウム/AlN-1 間の初期 接触角に及ぼす合金元素アルミニウムの影響を示す． $3 \% \mathrm{Al}$ 以下では初期接触角が大きいまま，ほとんど変わらないが， 去れ以上では接触角が若干減少し，10\% $\mathrm{Al}$ では115\%ねり， 濡孔性はやや向上する。

ただし，Mg-Al 合金系の $\gamma_{\mathrm{Iv}}$ に関するデータは報告されて いないので, Fig.6の結果について，さらに解析することは

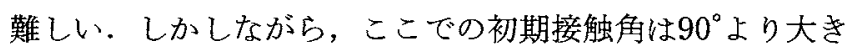
いので，式(2)から， $\gamma_{\mathrm{lv}}$ の值がアルミニウムの濃度上昇に 伴って大きくなるならば, Fig. 6 のように接触角は次第に低 下し，濡れ性は良くなるといえよう。すちろん，このことは 推定にすぎない。

\subsubsection{Mg-Zn 合金による濡れ}

Fig. 7 は $973 \mathrm{~K}$ に和けるマグネシウム/AlN-1 間の初期接 触角に及ぼす合金元素亜鉛の影響を示寸，要鉛の添加によ り，接触角は次第に低下し，5\% Zn では $111^{\circ}$ ，また，10\% Zn では107なった。しかしながら，この場合にも $\gamma_{\mathrm{sv}}, \gamma_{\mathrm{s} l}, \gamma_{\mathrm{lv}}$ の值はかなり複雑に変化すると考方られ，測定結果について 考察することは難しい，ただし，著者らの以前の研究8)によ れば，Mg-Zn 合金の蒸気圧は純マグネシウムより高く，固 気界面へのマグネシウム物よび亜鉛の吸着量が多いと考光れ ば，それにより，接触角は低下すると推定される。

\section{4. 結言}

ガラス状炭素，多孔質黒鉛执よび烇結 AlN の溶融マグネ シウムによる需れ性を測定し，基板の表面状態さらにはマグ ネシウム中の合金元素アルミニウム执よび亜鉛による濡れ性 への影響を検討し，次のような結果が明らかとなった。

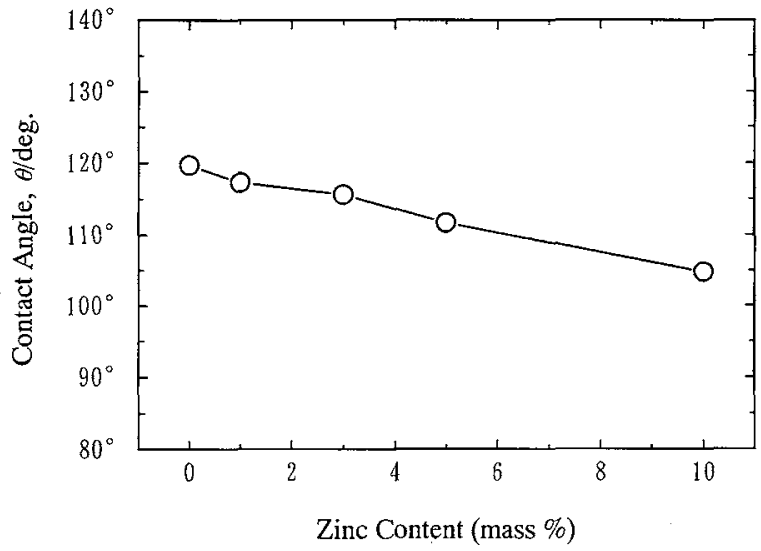

Fig. 7 Effect of zinc content on the initial contact angle between $\mathrm{Mg}-\mathrm{Zn}$ alloy drop and $\mathrm{AlN}-1$ substrate at $973 \mathrm{~K}$.

(1) $973 \mathrm{~K}$ K扣けるマグネシウム/ガラス状炭素系打よび マグネシウム/多孔質黒鉛系の初期接触角はとれぞれ $80^{\circ}$ と $74^{\circ}$ となり，良好な濡れ性が得られた。また，常温に打ける マグネシウム/ガラス状炭素系の界面の密着性は良く，界面 結合は強い，一方，マグネシウム/多孔質黒鉛系では，界面 に存在する気孔によって，基板と液滴の剥離が促された。

(2) $973 \mathrm{~K}$ K和けるマグネシウム/AIN間の初期接触角は $119^{\circ}$ とり，悪い濡れ性を示した。また，基板表面が粗面に なると，需れ性はさらに悪くなり，鋳型材料としての適用が 期待される。

（3）マグネシウム/A1N 基板系の接触角はマグネシウム中 にアルミニウムを添加すると，若干減少し，また，亜鉛を添 加すると，10\% Zn では $107^{\circ}$ となった。

本研究に括いて用いた AlN 基板は東洋アルミニウム株式 会社研究開発本部研究所，また，ガラス状炭素基板について は東海カーボン株式会社からご提供頂いたものでありここ に感謝の意を表します。

\section{文献}

1) K. Nogi and K. Ogino: J. Japan Inst. Met., 52(1988), 786-791.

2) N. Yoshimi, H. Nakae and H. Fujii: J. Japan Inst. Met., 52(1988), 1179-1186.

3) N. Mori, H. Sorano, A. Kitahara, K. Ogi and K. Matsuda: J. Japan Inst. Met., 47(1983), 1132-1139.

4) C. Toy and W. D. Scott: J. Mater. Sci., 32(1997), 3243-3248.

5) H. Fujii, H. Nakae and K. Okada: Matall. Mater. Trans., 24A (1993), 1391-1397.

6) W. Shi, M. Kobashi and T. Choh: Zeitschrift für Metallkunde, 90(1999), 294-298.

7) R. N. Wenzel: Ind. Eng. Chem., 28(1936), 988-994.

8) W. Shi, M. Kobashi and T. Choh: J. Japan Inst. Light Met., 49 (1999) , 291-295. 